\title{
Implementation of Malay Culture in History Subject
}

\section{Implementasi Kebudayaan Melayu dalam Pelajaran Sejarah}

\author{
Suroyo ${ }^{1}$, Bima Maulana Putra², Bedriati Ibrahim³ ${ }^{3}$ Yanuar $^{4}$, Asyrul Fikri ${ }^{5}$, Bunari ${ }^{6}$
}

1,3,4,5, 6Universitas Riau

${ }^{2}$ Universiti Kebangsaan Malaysia

\section{Corresponding Author}

Suroyo

suroy011002@lecturer.unri.ac.id +6281365221010

\begin{abstract}
History subject, as one of the topics with the capacity to mold the nation's character, should stress mentality or emotional intelligence as well as knowledge or academic intelligence. This study employs the Library Research approach, which entails gathering information and data from existing book sources such as Malay history and culture books, past journals, and historical knowledge books. This is part of the Malay culture's character, and character building in the Malay community may be used in any learning topic, particularly history subject. The goal of this study is to demonstrate how Riau Malay culture is being included into history classes. The problem in the area is that the Malay character is not accommodated in school learning; it is doubtful that this generation in Riau Province would conduct in accordance with the Malay personality. Otherwise, Malay culture is implemented or used in every subject, particularly history instruction. However, implementation Malay culture of Riau into history education may be an input and source of information where instructors can apply character development to pupils while also developing historical education understanding.
\end{abstract}

\section{Keywords}

implementation; Malay culture; history subject; students

\section{Abstrak}

Pembelajaran sejarah sebagai salah satu topik yang berpotensi membentuk karakter bangsa, hendaknya tidak hanya mengutamakan informasi atau kecerdasan akademik, tetapi juga mentalitas atau kecerdasan emosional. Hal tersebut merupakan bagian dari karakter budaya Melayu, di mana pembentukan karakter masyarakat Melayu dapat diimplementasikan kepada setiap topik pembelajaran, terkhusus pembelajaran sejarah. Tujuan dari penulisan ini adalah untuk menjelaskan tentang implementasi budaya Melayu Riau terhadap pembelajaran sejarah. Penelitian ini menggunakan metode Library Research, yaitu dengan mengumpulkan pengetahuan dan data dari sumber-sumber buku yang ada seperti buku sejarah dan budaya melayu, jurnal terdahulu dan buku pengetahuan yang berhubungan dengan sejarah. Permasalahan di lapangan ialah kepribadian Melayu tidak diakomodasi dalam pembelajaran di sekolah, kecil kemungkinan generasi di Provinsi Riau ini akan berperilaku sejalan dengan kepribadian Melayu. Sehingga, adanya implementasi atau penerapan budaya Melayu pada setiap pembelajaran terkhususnya pendidikan sejarah. Dengan demikian, Implementasi budaya Melayu Riau dalam pembelajaran sejarah dapat menjadi masukan serta sumber ilmu yang di mana guru dapat menerapkan pengembangan karakter pada murid serta mengembangkan ilmu pendidikan sejarah.

\section{Kata Kunci}

implementasi; budaya Melayu; pelajaran sejarah; siswa 


\section{Introduction}

Historical Subject, as topics with the ability to create the character of a nation, should place a premium not just on knowledge or intellectual intelligence, but also on emotional mentality or intelligence. History Subject is part of the endeavor to shape the nation's character in the future. The learning process is a series of activities that include learning preparation, implementation, and evaluation. Learning preparation is the preparation of study tools such as learning objectives, evaluation tools, teaching materials, learning method, media, facilities, time, place, funds, expects, and information tools required to support the learning process's implementation (Hartati, 2018). Character education is defined as instruction that instills character values in students (Firdaus, 2017; Karmedi et al., 2021). It is intended to create an environment of spirituality and excitement, as well as to offer inspiration for each component's human beings to continue striving for goals (Agung S., 2012; Rulianto \& Hartono, 2018; Umamah et al., 2017). History subject is supposed to give knowledge and debate about previous events or events that might help shape the attitudes and conduct of the nation's youthful generation (Bastian et al., 2019; Kusnoto \& Minandar, 2017). Learning local history implies that students may learn from the leadership styles of historical players, which they can use when they hold their different positions and job vocations (Amboro, 2019; Asmara, 2019; Wibowo, 2016; Widja, 2018).

However, the data of previous research reported that the description emphasizes the significance of inheriting historical values and the local wisdom of the Riau Malay community in learning history as part of an attempt to enhance students understanding of their historical and cultural values. History learning in schools is still repetitive; students do not grasp the necessity of studying history; and students do not realize that there are actual character values in every historical event (Jayusman \& Shavab, 2020; Jumardi \& Pradita, 2017). Instilling character values is the foundation for a child's life since a child's character development begins in the womb. Furthermore, students are taught character development through Malay culture. Children's personalities are shaped by Malay culture, which is rich in morality and religion (Sirnayatin, 2017; Sulistiawati et al., 2019;
Widja, 2018). In reality, with using learning media in the classroom is one of the things that may promote favorable learning activities. Because local history is the study of people's lives, particularly the community of a surrounding region (Afiqoh et al., 2018; Assidiq \& Atmaja, 2019; Putra et al., 2020).

Malay culture provides value in the form of counsel and attitudes employed in behaving, acting, working, and adjusting to one's surroundings with civility, mutual respect, and consideration. Deliberation in decisionmaking, equality of rights, collaboration, democracy, fairness, mutual respect, civility, mutual aid, and mutual cooperation are all principles that have crystallized. Deliberation in decision-making, equality of rights, collaboration, democracy, fairness, mutual respect, civility, mutual aid, and mutual cooperation are all principles that have crystallized. Malay environment that may be utilized as a source of mathematical difficulties as inspiration and abstraction of numerous historical notions and principles (Darto \& Putriani, 2019). Malay culture (Malays are mostly Muslims who speak Malay and follow and practice Malay cultural traditions (Raji et al., 2017) has become an important part of the people's customs in Riau Province (Tambak \& Sukenti, 2017). Because of the strength of this tradition, Malay culture is one of the Riau Province government's visions and missions in developing its territory, namely "the realization of Riau Province as the center of the Malay economy and culture in a religious, physically, and spiritually prosperous society in Southeast Asia by 2020" (Suroyo et al., 2017). The government established a regional rule concerning the Malay Customary Institution in response to the people of Riau's desire to establish Riau Province as a hub of Malay culture. Preservation is important in the context of growing Malay culture (Suroyo dkk., 2021b).

However, that the incorporation of Malay culture in history learning is an effort to preserve and preserve the community's customs and socio cultural values, particularly the moral, moral, and values that are at the heart of customs and habits in society, so that their existence is preserved and continues (Qodariyah \& Rizaldi, 2021; Suroyo et al., 2021a; Thalib, 2016). Students' lack of knowledge of Malay culture in primary schools is a result of a lack of techniques for applying the 
learning process in teaching Malay culture-based history in the classroom with traditional institutions that play a critical role in the development of Malay cultural traditions (Alirmansyah et al., 2019; Suroyo, 2019). The gap in this research is that the Malay culture is not accommodated in school learning; it is unlikely that this generation in Riau Province would behave in line with the Malay personality. Otherwise, Malay culture is included or utilized in all subjects, notably history. Incorporating Riau Malay culture into history education may serve as an input and source of knowledge for teachers to apply character development to students while also enhancing historical education comprehension. The aim of this research also to investigate how Riau Malay culture might be included into history subject as the problem statement of this research, the implementation of Malay culture in history subject, however, this research will give an overview about the implementation of Malay culture in Riau toward history subject in schools.

\section{Methods}

The aim of this study was to discover how students learn history using a contextual approach with the research used to design and test goods used in education and learning This study is in the form of Library Research with qualitative data, which is an attempt to collect information and data from textual sources in the library such as books, newspapers, periodicals, and documents related to the implementation of Malay culture in history subject. Library research and using contextual are believed to be the type of research to get a complex data and overview of implementation of in the implementation of Malay culture in history subjects. However, a Library research is used a data collecting approach that involves studying books, literature, notes, and various previous research papers that are relevant to current research. Humanities journal such as Malay culture articles on studying history in the 2013 Curriculum, as well as scientific journal articles about scientific methods and contextual approaches, are utilized as references in this article. The acquired data is logically and methodically organized and categorized.

The data analysis process begins with a review of all accessible data from multiple sources, such as journals which are related to history and Malay culture, field notes, personal, and papers official documents, photographic pictures, and others. As the procedure to get the result, after reading the full text, conclusions are reached by combining the most relevant points of debate into a single conclusion. The use of this method is due to several considerations, including the fact that this research is descriptive, which means that the data collected is in the form of words or reasoning, which is caused by the application of qualitative, data presentation is done directly. Data gathering and analysis are inextricably linked activities (Safi \& Bau, 2021).

\section{Results and Discussion}

The passing down of culture and local wisdom is a crucial component of growing up and developing one's identity. Culture is a way of life that emerges and is shared by a group of people, and it is passed down from generation to generation. Each region has a distinct culture from the others. This is owing to the fact that each region's demands are different. Culture evolves from generation to generation in response to the rising number of human demands, and it expands in all facets of life. This situation is exacerbated by the existence of several communities among these ethnic groupings, one of which is known as the Malay community in Riau. An indigenous community is a local entity that inhabits a certain territory and interacts on a continuous basis according to a set of customs. The Malay Culture in this context is the Malay culture are in Riau Province, there are Malay culture in Bengkalis, Siak, Pekanbaru, and other area in Riau. All of Malay Culture in Riau have similarity that the Province of Riau that the Authors get an object of Malay Culture in Riau generally.

Education is an endeavor to mold students' personalities so that they can see and discern between what is good and wrong in the lives of society, country, and state. Education is characterized not just as the transmission of information, but also as the transmission of values, particularly the ideals included in the 18character values addressed by character education. The goal of history subject is to increase students' awareness of themselves, society, and the process of developing the Indonesian country throughout a lengthy past that continues to the present and future. In reality, the aim of history subject has the aim that is similar to Malay Culture in Riau's characters that Malay culture is to be 
raised and developed. the community or generation must have a Malay personality that could do an implementation toward history subject.

If the Malays' characters are not accommodated in school learning, it is quite improbable that this generation in Riau Province would conduct in accordance with the Malays' personalities. The empirical understanding of this topic must be represented in the construction of Riau Malay culture in society. Coupled with today's young generation's personality has a propensity that is less expressed in portraying a noble nature. Meanwhile, developing Malay self-identity from a personality standpoint is critical at this period. In terms of personality, the Malays' identify or identity is "sulking." prefers to convey things in an indirect or rhymed manner, is sentimental as reflected in Malay songs, because every conflict between himself and others is then drawn into him, peaceful and tolerant or reject and "gamok" or rage which is manifested when what has been experienced has made a Malay very ashamed or made him suffer from a heart that is difficult to bear anymore.

Circumstances indicating harmony and attainment of well-being in bodily and spiritual existence Increased selfcontrol, self-awareness, and instilling religious and cultural values in daily life are all ways to improve mental health. Aspects of Malay culture such as mutual respect, methods of communicating, and interactions between members of the community and others must be an identity that students must apply in community life and that must be incorporated in the curriculum. The major capital for the emergence of mental health for the Riau Malay population is the harmony of good interactions. Local culture (Malay) is the same as achieving a nation's self-awareness; local culture, together with national culture, also helps to developing a picture of the essential essence of humanity, Indonesian people who live with optimism for the future.

In terms of the utility or goal of studying history, historical learning plays a critical role. Historical learning is meant to instill in pupils a desire to study and be conscious of history in their daily lives as people and countries. Studying history refers to learning history; hence, a range of historical learning methodologies must be developed. Furthermore, connecting the past, present, and future is viewed as a fictitious act and a waste of time. According to academics, history is the most essential factor in the building of a civilization. It invites humans to briefly reconstruct memories in order to convey the values of an event that surrounds them. "Who controls history controls the future, and who controls the present controls history."

This sense of the future must be preserved constantly throughout history instruction, both in terms of local and national culture. Studying the nation's history is the most important capital in constructing a nation today and in the future, as it serves as the foundation for the establishment of national identity and the formation of national character or character. Understanding history entails studying life as a whole, including the individual, society, and nation. Various events in Indonesian history have significance for the Indonesian people and nation, requiring the attention of all parties, including educators, students, and historians. The function of the class facilitator in connecting instructional materials with Riau history based on Riau Malay culture cannot be separated from students' comprehension of local history.

Students are tasked with taking out direct actions in the field, particularly in their local surroundings, to research historical traces and gather historical information in order to aid develop knowledge and appreciation of historical values. Students in the learning process can obtain direct experience in tracing historical traces in their surroundings through this exercise, in addition to receiving knowledge from educators as facilitators and libraries. Students can also view, watch, study, and acquire knowledge from community leaders in their immediate surroundings. Students are given the chance to communicate the local history that they learn as a consequence of field activities.

The facilitator views local history not just as a science, but also as a tale that awakens feelings of love for one's hometown, responsibility, and tolerance. The spirit should be recognized from this. Heroism, religion, national spirit, and love for the motherland are deeply ingrained in pupils. Several national cases, such as corruption, law enforcement, and general elections, both presidential and gubernatorial elections, actually contributed negatively to students' understanding of 
contemporary history while simultaneously increasing students' understanding of local history toward national heroes and local heroes. Educators maximize the allocation of time for learning history in classrooms by including local history content in accordance with the historical material being studied.

Students gain examples and experiences from many phases of environmental development in their community, including their current condition, when they learn based on local historical values. Students will also be encouraged to acquire specialized skills such as observation, questioning or conducting interviews, identifying sources, locating information, and so on. It is simple to promote intercultural ideals in students. Multiculturalism is a notion in which a community recognizes variety, distinctions, and cultural pluralism, including race, ethnicity, ethnicity, and religion. A multicultural nation is one in which existing ethnic and cultural groups may coexist peacefully under the coexistence principle, which is defined by a willingness to appreciate other cultures.

This plurality is likewise caught by religion, and religion controls to preserve the plural society's equilibrium. If students understand history properly, they will develop empathy and tolerance for others, as well as mental talents for inventiveness and credulity. However, teaching national history in schools will expose pupils to his people's collective and previous experiences. This education also promotes consciousness in regard to a common existence in a broader community, resulting in a greater collective knowledge of having oneness in history. This self-recognition process is the beginning point for a sense of self-esteem, togetherness, and attachment, a sense of grade and owning (a sense of belonging), and finally a sense of national and national pride.

Several factors must be addressed in history subject, including the initial process presentation, both learning approaches, and the three evaluations employed. As previously said, the learning technique of history subject should not just depict history as an event. Local learning of local history must also follow the overall trend of historical writing growth with the implementation of Malay Culture. The evolution of history writing is documented by stressing analysis rather than storytelling; emphasizing themes or subjects rather than chronology; relying on data, oral interviews, sociological models, and psycho-analysis theory. This may be accomplished via critical thinking skills development in students, especially with the implementation of Malay Culture that could increase the knowledge of history field, especially in local history.

Studying History Based on Malay culture, it is possible to convert in school through national history study. In another sense, local events can be incorporated into national history learning by searching for the theme of the theme or subject matter in the national history syllabus and is described in the form of a modification to the Learning Implementation Plan (RPP) that develops students' thinking creativity. Studying history, despite the fact that the content addresses previous events, the events will be history in the future. The existence of a repeatable historical motion pattern in history is in terms of the utility or goal of studying history, historical learning plays a critical role. Historical learning is meant to instill in pupils a desire to study and be conscious of history in their daily lives as people and countries. That is the reason of Malay Culture could give an implementation of the culture in History subject in Riau.

Studying history refers to learning history; hence, a range of historical learning methodologies must be developed. The notion of "critical education" refers to an educational process that leads to the realization of emancipator critical individuals who are critically capable and eager to change their lives with their own power (autonomous human). Learn from history (past experience) as inspiration to respond to any difficulty in the present and future to live a better life. Analytically, history learning is founded on this new paradigm, which begins with the interplay of three fundamental notions related to history learning.

\subsection{History Subjects in 12 Years Schools}

The position of history learning in schools varies; in elementary and junior high school, it is included in the social studies topic; in high school, it is a stand-alone subject; and in vocational schools, it is part of Civics. This position has a significant impact on the performance of history learning in schools. History 
courses in elementary and junior high school must adapt to academic and technological content challenges that cannot be avoided since they do not stand alone. The problem of academic content is concerned with the location of historical information in the social studies topic, as well as technical issues with training teachers and the division of study hours. These two concerns will be addressed in separate chapters especially the implementation of Malay Culture that could be applied in local history.

Academic and technological challenges are not as complex at the SMA and SMK levels as they are at the SD and SMP levels. So far, the concerns have centered on technical difficulties, such as the fact that the amount of time allotted for the history course varies from department to department, despite the fact that the content to be finished is not significantly different. The first academic challenge is the link between history and social studies; the second is how to combine Malay culture of Riau's information with social studies areas such as geography, economics, and sociology of Malay community could be learned. Social Studies is a topic of study that integrates various resources from the social sciences for educational objectives such as Malay historical sites and cultures.

The goal of Social Studies is to provide students insight into information so that they may become decent and intelligent citizens who understand and can carry out their rights and duties as citizens. The core structure of social studies has three elements: civic education, a foundation for teaching social sciences, and a mechanism to expose students to real-world problems in their communities. Because history is part of the humanities scientific family, historical material only has a direct link with the first aspect, while the second element is currently being contested. The link with the third element is frequently denied due to a lack of comprehension of history; history is thought to only focus on previous topics and is "impossible" to apply to students' present lives. The issue is that there are so many historical texts that should be studied at the elementary and junior high school levels over such a lengthy period of time, even though the local culture in Riau is necessary to be learned especially in 12 years school.
History content in elementary school social studies begins in grade 2 in semester 1 , with the substance of presenting living history with the topic of family history, in this context, could give an implementation of Malay culture such as Malay poetries and others. Class 3 semester 2 contains a lot of information on the history of money, and class 4 semester 1 has a lot of material on 1) local historical heritage (around the regencies and provinces) and conservation efforts, and 2) imitating the heroism and patriotism of the characters in their region. Class 5 semester 1 covers a wide range of topics, including Hindu-Buddhist and Islamic history, as well as getting to know the characters however, Malay cultures had been influenced of Hindu-Buddha in the past that are Buddha kingdom before Islamic kingdom in Riau. Class 5 semester 2 of the Social Studies topic is entirely devoted to historical information, ranging from the challenges of the Dutch era through the battle to retain independence. History is no longer taught in social studies classes in grades 6 and 7 . The history content in elementary and junior high school social studies disciplines is highly wide and is studied independently from other social studies subjects such as economics, geography, and sociology.

Learning local history entails making pupils aware of their own past. They take satisfaction in the fact that long before they were born, various people played a role in forming the conditions linked with the present. This understanding of continuity and location may be used by pupils to demonstrate their historical, social, and cultural identities and more pupils who participate in the research of local history, the stronger their sense of identification and pride in the group's past, location, and culture.

Local history learning gives students more active opportunity to investigate knowledge outside of the intended objectives. Students get more familiar with the social aspect of historical players as they learn about caregivers, cultural guardians, and cultural officers. How historical players fought for great ideological ideas in accordance with the backdrop of oneness in life at the time will encourage students to do the same now. Is the area important socially, or is it merely a sliver of the Hindu-Buddhist power system with the Riau Malay? This historical understanding may energize people to 
make constructive changes in the present. When students realize that the central government does not play a substantial role in their field (environment), they get disillusioned.

Learning local history implies that students may learn from the leadership styles of historical players, which they can use when they hold their various positions and professions. The spirit of historical actors who stress discourse and consensus in making decisions encourages students to make policy decisions later in their careers when they are already working. When students have taken positions in jobs and enterprises, the attitude of mutual collaboration gives great motivation for students to boost work ethic and production. The willingness to sacrifice and prioritize shared interests can obviously be transferred to the world of work without discriminating among social and cultural backgrounds, allowing the organization to achieve great job performance. Exposure to local history may help children comprehend diverse historical events in their neighborhood as well as historical occurrences in other locations especially the Malay Culture in Riau that have local histories and characters that could be learned. Morewise, students in Riau could be represented the culture by giving advantages of positive character of Malay communities in Riau.

\subsection{Implementation of Malay Culture in History Subject}

History based on Malay culture is one of the fields of historical science that plays a significant role in the advancement of history and historical education in a history that takes place in a specific location and has a particular identity binding force. One of the purposes of historical education is to serve as a vehicle for cultural preservation. In actuality, IPS does not become social studies, but rather the coordinator of the four topics that comprise it. Learning history opens the way to understanding and wisdom for what has occurred. Knowing about history entails learning about mankind in all of its facets. Learning history will give birth to an understanding of the nature of human culture and civilization's growth, the consequence of which will be known as historical consciousness. However, one of the goals of learning history is to foster historical awareness such as Increase students' knowledge of the significance of time and location, which is a process that spans the past, present, and future, improve students' critical thinking skills by teaching them how to accurately analyze historical facts using scientific techniques and procedures.

The goal of Malay culture-based history subjects is to increase students' appreciation and appreciation for historical heritage as evidence of the Indonesian nation's civilization in the past, as well as to increase students' understanding of the process of forming the Indonesian nation over a long history that is still ongoing until the present and the future. The government's historical subjects are actually rather excellent; nevertheless, the operational description still has to be restructured. Based on the objectives and what was learnt, at the very least, instructors and connected parties should be encouraged to take efforts that will assure the attainment of the aforementioned learning history objectives. That is, a learning process that ensures the accomplishment of the necessary competences and goals must be pursued.

An implementation approach to history learning, that is, studying history based on Malay culture. Despite the fact that in this day and age, his presence can be substituted by technology, is still required for historical learning with Malay Culture. The teacher is not simply a facilitator who aids in the learning process; They is also a designer of how the learning process should and should not take place. Several needs must be met by the history instructor in the framework of optimal history learning. A history teacher must have the following qualifications which must be academically capable (can be read: master the material). This fact also demonstrates the low level of dedication to incorporating character education into kids' daily life in the classroom through historical study.

In fact, history teachers have a sufficient understanding of the ideal character of character education, which must be realized or implemented of Malay Culture in everyday life by providing opportunities for the development of a responsible attitude in responding to challenges in the present and future, as well as having an awareness of positive values. History subject and Malay culture are well-versed in models, techniques, approaches, and procedures. For the development of character education, activities, media, and learning tools, as well as evaluation of successful 
historical learning, are used. In fact, students understand the steps for preparing a history lesson plan for character education, which is interpreted as an effort to instill positive values from the history of the nation's struggle that can be implemented in everyday life, and they also agree that history learning is the best form of character education development pattern, especially the Malay Culture that could be implementation to increases the knowledge of local history and history subject in school.

Furthermore, history subjects must have teacher qualifications and competences in order to inculcate and develop character education in their students. These teacher qualifications and competencies must promote the attainment of character education via history learning. However, due to the restricted number of hours available for teaching history with solid content and history classes that are still secondary, teaching local history is not optimum. To address this, the instructor took the initiative by assigning students to research local history in the region surrounding the school. Students have a better understanding of local history as a result of the process of recognizing local history. The recognized local history includes not only tangible pieces of historical significance, but also oral or folklore local history.

Historical location is a type of identification or a person's life identity that is related to Malay Culture in Riau. Identity is described as the traits or signals that explain and are consistent with one's understanding of one's own self, group, group, community, or nation. In History classes, before examining students' grasp of the local history learning process. It's a good idea to first grasp what the term "locality" means. As the aspect of implementation, Historical cultures in Malay culture such as local heritage of Malay and Malay traditional arts (music, arts, and others) refers to the understanding of one's own identity in terms of consistent and evolving subjective sensations across time. The vulnerabilities that emerge in History Subject Study Program for students, particularly throughout the process of learning local history that Riau is a geographical location of the Unitary Republic of Indonesia (NKRI) with historical locality potential. The implementation is necessary due to the characteristic of Malay culture and the aim of history subject is.
When people look at the facts, they will notice that much of the local history has not been exposed, and even study on area history is still inadequate. This is the root cause of pupils' lack of understanding of local or regional history. Morewise, the effect of implementation of Malay Culture in History Subjects is that the issue is that material in the form of regional history books and knowledge from schools or teachers is quite limited. As a result, comprehension of historical location is quite limited. In this regard, the findings of interviews with various students who took local history courses over the even semesters reveal that knowledge of the history of their individual regions is known when participating in the lectures delivered by the lecturers by implementation of Malay culture in Riau. One of the causes for the lack of attention paid to local history study and writing is the vastness of Riau. The lack of original materials, the difficulty in locating physical facts, and the interests of researchers are all reasons for not exposing Malay Culture in Riau.

\section{Conclusion}

Historical learning contributes to the formation of the nation's character for the younger generation through formal education, which is expected to generate a moral historical consciousness capable of inspiring nationalism. Historical learning, as a topic with the potential to shape a nation's character, should prioritize not only information or academic intelligence, but also emotional mentality or intelligence. It is part of the effort to form the character of the nation in the future the learning process consists of several actions such as learning preparation, execution, and assessment. Circumstances suggesting peace and well-being in physical and spiritual life Improving mental health may be accomplished by increased self-control, self-awareness, and imparting religious and cultural values in daily life. Mutual respect, communication strategies, and interactions between members of the community and others must be aspects of Malay culture that students must employ in community life and that must be included into the curriculum. The harmony of positive contacts is a vital capital for the emergence of mental wellness for the Riau Malay community. Local culture (Malay) is synonymous with attaining a nation's self-awareness; local culture, together with national culture, also contributes to the 
development of a picture of the fundamental essence of mankind, Indonesians who live with hope for the future. Local History Research.

The result and output of implementation of Malay culture in history subjects is feasible to convert in school through national history education based on Malay culture in Riau. Local events can also be included into national history learning by looking for the theme of the theme or subject matter in the national history syllabus, which is described in the form of a change to the Learning Implementation Plan (RPP) that promotes students' thinking creativity, the role model of Malay history such as Hang Jebat, Hangtuah, and Sultan of Siak and other role of Malay culture could be implemented in History subject, due to the role has characteristic that history subject's aim is similar. In terms of the value or objective of studying history, the existence of a recurring historical motion pattern in history plays a significant role. Historical education is intended to create in students a drive to study and be aware of history in their everyday lives as individuals and countries especially in Malay culture to increase the awareness of local culture. Because studying history entails learning history, a variety of historical learning strategies must be established. The term "critical education" refers to an educational process that results in the development of emancipator critical persons who are critically capable and willing to improve their life via their own power (autonomous human). Learn from history (past experience) as inspiration to respond to any challenge in the present and future in order to live a better life. Analytically, history learning is based on this new paradigm, which begins with the interaction of three key historical concepts. Otherwise, the form of implementation of Malay culture in History subject could be applied in 12 years school to give a complex policy of curriculum in Riau for students. The awareness of Malay culture as the local culture in Riau could be the reason to government to give an overview of implementation of Malay culture toward History subject in 12 years School in Riau.

\section{Acknowledgment}

Thank you for the Education Office, Cultural Service, then a historical education study program that can provide values and data in the form of research and previous knowledge books that help get the results of this study. Not forgettingly thanks to Salus Cultura who has opened the opportunity for the Authors in completing this research, giving input, and becoming a facilitator in the issuance of this research.

\section{References}

Afiqoh, N., Atmaja, H. T., \& Saraswati, U. (2018). Penanaman Nilai Kearifan Lokal dalam Pembelajaran Sejarah Pokok Bahasan Perkembangan Islam di Indonesia pada Siswa Kelas X IPS di SMA Negeri 1 Pamotan Tahun Ajaran 2017 / 2018. Indonesian Journal of History Education, 6(1), 42-53. https://journal.unnes.ac.id/sju/ index.php/ijhe/article/view/27353

Agung S., L. (2012). Pengembangan Model Pembelajaran Sejarah SMA Berbasis Pendidikan Karakter di Solo Raya. Jurnal Pendidikan dan Kebudayaan, 18(4), 412-426. https://doi.org/10.24832/jpnk.v18i4.98

Alirmansyah, Destrinelli, Irani, V. S., Karomah, R., Riski, R. D., Amri, K., Setianingtyas, W., Putri, N. H., \& Hendriyati, B. (2019). Implementasi Budaya Melayu Jambi Melalui Mata Kuliah Pengenalan Adat Melayu Jambi pada Mahasiswa PGSD Universitas Jambi. Jurnal Inovasi Pendidikan dan Pembelajaran Sekolah Dasar, 3(2), 25-35. https:// doi.org/10.24036/jippsd.v3i2.107404

Amboro, K. (2019). Kontekstualisasi Pandemi Covid-19 dalam Pembelajaran Sejarah. Yupa: Historical Studies Journal, 3(2), 90-106. https://doi.org/10.30872/yupa.v3i2.203

Asmara, Y. (2019). Pembelajaran Sejarah Menjadi Bermakna dengan Pendekatan Kontektual. Kaganga: Jurnal Pendidikan Sejarah dan Riset Sosial Humaniora, 2(2), 105-120. https://doi.org/10.31539/ kaganga.v2i2.940

Assidiq, N. F., \& Atmaja, H. T. (2019). Implementasi Kearifan Lokal dalam Pembelajaran Sejarah terhadap Apresiasi Siswa SMA/MA Berbasis Islam di Kabupaten Wonosobo. Indonesian Journal of History Education, 7(1), 79-92. https://doi.org/10.15294/ijhe.v7i1.32288

Bastian, A., Suharni, \& Novitasari, Y. (2019). Permainan Tradisional Berbasis Budaya Melayu dalam Pengembangan Karakter Anak. Atfōluna: Journal of Islamic Early Childhood Education, 2(2), 53-56. https://doi.org/10.32505/atfaluna.v2i2.974

Darto, \& Putriani, Z. (2019). Pengembangan Model Pembelajaran Matematika Problem Solving Berbasis Budaya Melayu. Prosiding Konferensi Nasional Penelitian Matematika dan Pembelajarannya (KNPMP) IV 2019. https://publikasiilmiah.ums.ac.id/handle/ $11617 / 10889$

Firdaus, D. W. (2017). Pewarisan Nilai-Nilai Historis dan Kearifan Lokal Masyarakat Kampung Adat dalam Pembelajaran Sejarah. Jurnal Artefak, 4(2), 129-134. https://doi.org/10.25157/ja.v4i2.906

Hartati, E. (2018). Pembelajaran Sejarah Indonesia Berbasis PeristiwaPeristiwa Lokal di Kalimantan Tengah untuk Meningkatkan Kemampuan Berpikir Kritis. Jurnal IImiah Kanderang Tingang, 9(1), 39-50. https://doi.org/10.37304/jikt.v9i1.5

Jayusman, I., \& Shavab, O. A. K. (2020). Aktivitas Belajar Mahasiswa dengan Menggunakan Media Pembelajaran Learning Management System (LMS) Berbasis Edmodo dalam Pembelajaran Sejarah. Jurnal Artefak, 7(1), 13-20. https://doi.org/10.25157/ja.v7i1.3180

Jumardi, \& Pradita, S. M. (2017). Peranan Pelajaran Sejarah dalam Pengembangan Karakter Siswa Melalui Pembelajaran Berbasis Nilai Sejarah Lokal di SMA Negeri 65 Jakarta Barat. Jurnal Pendidikan Sejarah, 6(2), 70-80. https://doi.org/10.21009/JPS.062.08

Karmedi, M. I., Firman, \& Rusdinal. (2021). Pendidikan Karakter dalam Pembelajaran Sejarah Selama Pandemi Covid-19. Journal of Education Research, 2(1), 44-46. https://doi.org/10.37985/jer.v2i1.45

Kusnoto, Y., \& Minandar, F. (2017). Pembelajaran Sejarah Lokal: Pemahaman Kontens bagi Mahasiswa. Sosial Horizon: Jurnal Pendidikan Sosial, 4(1), 125-137. https://doi.org/10.31571/ sosial.v4i1.428

Putra, E. D., Ramadhan, Z. H., \& Mulyani, E. A. (2020). Peningkatan Pengetahuan Budaya Melayu Melalui Pembelajaran Berbasis Kontekstual (CTL) Kelas IV SDN 191 Pekanbaru. Tunjuk Ajar: Jurnal 
Penelitian IImu Pendidikan, 3(1), 56-61. https://doi.org/10.31258/ jta.v3i1.59-64

Qodariyah, A. L., \& Rizaldi, M. (2021). Analisis Pembelajaran Sejarah pada Kurikulum 2013 dengan Pendekatan Saintifik dan Kontekstual. Chronologia, 2(3), 25-32. https://doi.org/10.22236/jhe.v2i3.6439

Raji, M. N. A., Ab Karim, S., Ishak, F. A. C., \& Arshad, M. M. (2017). Past and present practices of the Malay food heritage and culture in Malaysia. Journal of Ethnic Foods, 4(4), 221-231. https://doi.org/ 10.1016/j.jef.2017.11.001

Rulianto, \& Hartono, F. (2018). Pendidikan Sejarah Sebagai Penguat Pendidikan Karakter. Jurnal IImiah IImu Sosial, 4(2), 127-134. https:/ /doi.org/10.23887/jiis.v4i2.16527

Safi, J., \& Bau, S. O. (2021). Pemanfaatan Situs Sejarah di Ternate sebagai Sumber Pembelajaran. Historia: Jurnal Program Studi Pendidikan Sejarah, 9(2), 107-116. https://doi.org/10.24127/hj.v9i2.3592

Sirnayatin, T. A. (2017). Membangun Karakter Bangsa Melalui Pembelajaran Sejarah. SAP (Susunan Artikel Pendidikan), 1(3), 312-321. https://doi.org/10.30998/sap.v1i3.1171

Sulistiawati, M., Yusnadi, Sembiring, R. R., \& Husnika, E. (2019). Implementasi Pendidikan Karakter Melalui Budaya Melayu pada Anak Usia Dini 4-6 Tahun di Paud Cendana Kecamatan Pantai Labu. Journal of Millennial Community, 1(2), 65-72. https://doi.org/ 10.24114/jmc.v1i2.14753

Suroyo. (2019). Ringkasan Disertasi: Ritual Bedekeh Suku Akit di Pulau Rupat Kabupaten Bengkalis Provinsi Riau pada Era Global. Masyarakat Indonesia, 44(2), 88-97. https://doi.org/10.14203/ jmi.v44i2.806

Suroyo, Putra, B. M., \& Ibrahim, B. (2021a). Cultural Belief of Petang Megang Ritual with Self Actualization on Malay Community Pekanbaru City Riau. Udayana Journal of Social Sciences and
Humanities, 5(2), 64-67. https://ojs.unud.ac.id/index.php/UJoSSH/ article/view/77653

Suroyo, Putra, B. M., \& Ibrahim, B. (2021b). Pengembangan Bandar Senapelan Sebagai Wisata Sejarah Jalur Rempah. Santhet: Jurnal Sejarah, Pendidikan dan Humaniora, 5(2), 147-155. https://doi.org/ 10.36526/js.v3i2.e-ISSN

Suroyo, Wirata, G., \& Kamaruddin, K. (2017). Strategi Pengelolaan Pariwisata Budaya Ritual Bedekeh Suku Akit di Pulau Rupat Kabupaten Bengkalis Provinsi Riau. Proceeding TEAM, 2, 33. https:// doi.org/10.23887/team.vol2.2017.153

Tambak, S., \& Sukenti, D. (2017). Implementasi Budaya Melayu dalam Kurikulum Pendidikan Madrasah Ibtidaiyah di Riau. Miqot: Jurna IImu-ilmu Keis/aman, XLI(2), 361-383. https://doi.org/10.30821/ miqot.v41i2.409

Thalib, M. (2016). Implementasi Visi Riau 2020 pada Lembaga Adat Melayu Riau. Jurnal IImu Administrasi Negara, 14(1), 39-45. https:// jiana.ejournal.unri.ac.id/index.php/IIANA/article/view/3419

Umamah, N., Sumardi, \& Wahyuni, E. S. (2017). Pengembangan Cerita Sejarah Gayatri Sri Rajapatni Perempuan Pembangun Imperium Majapahit pada Mata Pelajaran Sejarah SMA. Pendidikan dan Humaniora, 55(1), 63-68. http://repository.unej.ac.id/handle/ $123456789 / 80413$

Wibowo, A. M. (2016). Pengembangan Model Pembelajaran Sejarah Lokal di SMA Kota Madiun. Agastya: Jurnal Sejarah dan Pembelajarannya, 6(1), 46-57. https://doi.org/10.25273/ajsp.v6i01.880

Widja, I. G. (2018). Pembelajaran Sejarah yang Mencerdaskan Suatu Alternatif Menghadapi Tantangan dan Tuntutan Jaman yang Berubah. Jurnal Pendidikan Sejarah Indonesia, 1(2), 117-134. https:// doi.org/10.17977/um033v1i22018p117 